\title{
Bad Luck, No Luck, Good Luck!
}

\author{
Arthur M. Michalek ${ }^{1}$ \\ Published online: 29 March 2015 \\ (C) American Association for Cancer Education 2015
}

In 1965, Frank Sinatra recorded one of my favorite songs entitled "Luck Be A Lady" [1]. In 2014, Tomasetti and Vogelstein reported on a work of theirs which also focused on "luck" [2]. The song crooned by Sinatra was originally penned for Guys and Dolls and was about whether the singer's good luck would enable him to capture the girl of his dream. Tomasetti and Vogelstein opined whether one's risk of developing cancer was a matter of "bad luck" and not attributable to factors under anyone's control. Their article engendered some vociferous reactions that reminded me of the Hans Christian Andersen story "The Emperor's New Clothes" [3]. Were they heretics? Did they come upon some revelation that would result in a paradigm shift in our study of cancer etiology? Do their findings provide a rationale for the incongruities within the epidemiologic literature? The answers to these questions are not obvious and will take considerable more research. In essence, what they reported was that not all cancers are due to genetic and/or environmental insult and that the risk of developing specific cancers may be more a factor of the total number of stem cell divisions. They state that "only a third of the variation in cancer risk among tissues is attributable to environmental factors or inherited predispositions." Their findings are based on a review of site specific incidence data as well as biologic rationale. For example, they state that "cancers of the small intestinal epithelium are three times less common than brain tumors, even though small intestinal epithelial cells are exposed to much higher levels of environmental mutagens than are cells within the brain, which are protected by the blood brain barrier." They conjecture that if environmental factors cannot explain this difference, then perhaps we might look to lifetime number of stem cell divisions hypothesizing that those sites with higher numbers of stem cell divisions will incur more random changes resulting in cancer development. I do not intend to present a fully fleshed

Arthur M. Michalek amm3@buffalo.edu

1 Division of Health Services Policy \& Practice, University at Buffalo, Buffalo, NY, USA synopsis or critique, but rather put this forward for your consideration and encourage each and every one of you to review and reflect upon this work. It does not attribute every cancer to bad luck. Many sites of cancer may be attributed to environmental exposures some of which are directly related to personal behavior and of modifiable risk. The article does, per the Andersen story, require us to take a step back and re-examine the basis of our own work. A number of the cancer sites focused on in this Journal are those categorized as risk modifiable and, therefore, we should continue in our efforts to reduce exposures. For all sites, including those likely related to "bad luck," we need to discover effective means of earlier detection. Thus, efforts made to improve access to and utilization of established and future screening modalities represent sources of good luck even for those experiencing bad luck. This dovetails nicely with our efforts to increase awareness of and compliance with evidence-based guidelines in cancer screening. Regardless of the role of "luck," we as cancer educators have much work to do.

Now for some good luck...I realize that it is only spring, but after the brutal winter most of us have endured, we are more than ready to contemplate life in a warmer climate. Mark your calendars for October 21-23 when the International Cancer Education Conference will be held in Tucson, Arizona. This meeting is co-organized by the American Association for Cancer Education (AACE), the Cancer Patient Education Network (CPEN), and the European Association for Cancer education (EACE). Tucson is known by many names including the following: the Old Pueblo, Optics Valley, and the Sunshine Factory. Whatever you call it, the weather is guaranteed to be warm and sunny and the meetings engaging and educational. So pack your sunscreen lotion, grab your presentation material and join your fellow cancer educators for that wonderful annual ritual... the annual meeting! The theme of this year's conference is Cancer Education in Diverse Populations: Disparities, Genomics and Innovations. This truly is an international meeting drawing participants from the far corners of the globe which adds to the depth and breadth of presentations. The organizers stress that this conference provides a showcase of validated educational models provides a multidisciplinary forum for the dissemination of cancer education 
research, facilitates interdisciplinary networking, and enhances attendees educational and evaluation skills. The goals as stated by the conference organizers are to expand the cancer education community from which we can learn and share best practices in cancer education, making best use of our educational efforts. For anyone who has attended these meetings, they are recalled as a gathering place of like-minded individuals to learn new skills through preconference and plenary presentations, sharing successful strategies, and networking. Personally, I've also found it to be an energizing atmosphere. One cannot help but to leave the meetings in an upbeat, enthusiastic state of mind after being exposed to so many great works by so many committed individuals. There is no better way to find out what these meetings are about than to review what they have been. For a sampling of past programs, please visit the website http://www.aaceonline. com/PastMeetings.html. I encourage everyone who is reading this editorial to seriously consider participating in this year's meeting. Full details including information on abstract presentation, venue, travel, etc. may be found at the website http://2015.attendicec.org/.

If you are considering attending and may be somewhat short of travel funds, the Association funds several awards for which you may be eligible. There is the Selma Morris Memorial Travel Scholarship Award which provides some funding for individuals who are presenting a work focused in global cancer education. Dr. Morris was an expert in breast cancer and initiated a number of innovative programs in countries such as Burundi, Georgia (the country as well as having developed similar programs in the State), and Zambia. There also is the Joseph F. O'Donnell Early Career Investigator Award which provides up to $\$ 1500$ to support attendance to present at the meeting. Dr. O'Donnell is one of the cornerstones of the Association and past Editor-in-Chief of this Journal who has had a lifelong involvement in encouraging and mentoring early investigators in the field of cancer education. And for those of you who may be presenting, don't forget to submit your manuscript for consideration of the R. Davilene Carter Presidential Prize for Best Manuscripts. Dr. Carter was a past president of the AACE who strove for and maintained the highest standards for cancer education. Greater detail on these awards may be found at the AACE website (http://www. aaceonline.com/). You may also contact me with any questions or concerns.

Finally, I am sad to announce that Ky'esha Hammond Schoolfield has left Springer. Ky served as a Senior Editor at Springer and was responsible for overseeing the Journal of Cancer Education. Ky was well known for her positive personality, attention to detail, patience, compassion, dedication, responsiveness, and commitment to excellence. She possesses a long list of attributes and will be deeply missed by all. I wish her only the best in wherever road she takes. Thank you Ky!

Be well.

Arthur M. Michalek, PhD, FACE

\section{References}

1. Sinatra '65: The Singer Today is a 1965 compilation album by Frank Sinatra

2. Tomasetti C, Vogelstein B (2014) Variation in cancer risk among tissues can be explained by the number of stem cell divisions. Science 347(6217):78-81

3. Andersen, HC. The Emperor's New Clothes 